\title{
EVOLUCIÓN DEL TRATAMIENTO DE LA COLUSIÓN EN CHILE DENTRO DEL MARCO DE LA DEFENSA DE LA LIBRE COMPETENCIA
}

\author{
Evolution of treatment in Chile collusion within the \\ framework of the defense offree competition
}

Francisco Sanz Salguero*

Pontificia Universidad Católica de Valparaíso Valparaíso, Chile

* Doctor en Derecho, Pontificia Universidad Católica de Valparaíso. Abogado, Universidad Externado de Colombia. Profesor, PUCV. Dirección postal: Avenida Brasil 2950, Valparaíso, Chile. Correo Electrónico: fjsanzsalguero@hotmail.com.

Artículo recibido el 18 de mayo de 2018 y aceptado para publicación el 13 de julio de 2018 
RESUMEN: El presente trabajo aborda, desde una perspectiva histórico-jurídica, la evolución de la figura de la "colusión" dentro del marco normativo chileno. El análisis se realiza examinando las causas que han generado este cambio en el tratamiento normativo de las conductas colusorias, hasta llegar a la regulación actual del sistema de defensa de la libre competencia, concretamente en lo que respecta al combate de la colusión en materia económica.

PALABRAS CLAVES: colusión, sanciones, derecho de la competencia.

ABSTRACT: The present work accost, from a legal-historical perspective, the evolution of the concept of "collusion" within the Chilean regulatory framework. The analysis it is made by examining the causes that have generated this change in the normative treatment of collusive conducts, up to the current regulation of the defense system of free competition, particularly with regard to combating collusion in economic matters.

KEYWORDS: Collusion, sanctions, competition Law. 


\section{INTRODUCCIÓN}

Como fenómeno de carácter comercial, la colusión es una de las conductas capaces de generar daño al funcionamiento de la economía, toda vez que socava los beneficios propios de la competencia y la rivalidad entre empresas, impidiendo que el consumidor disfrute de menores precios, mayor variedad y mejor calidad en los bienes y servicios que consume. Junto con las prácticas colusivas, otras de las conductas atribuibles a los agentes económicos que pueden menoscabar el desarrollo de la libre competencia son el abuso de la posición dominante y las prácticas predatorias o de competencia desleal.'

Bajo esta óptica y desde una perspectiva general, la colusión es una práctica en la que empresas que compiten en un mismo mercado acuerdan subir precios, repartirse aquél o bloquear el ingreso de nuevos competidores, incluyéndose como ejemplos de prácticas colusivas los acuerdos explícitos o carteles, cuyo objetivo es fijar precios, limitar la producción o repartirse el mercado ya sea geográficamente o por tipo de cliente. ${ }^{2}$

En el ámbito nacional y teniendo como fundamento la definición de práctica colusoria establecida en el Decreto Ley $n^{0} 211$ de 1973, ${ }^{3}$ a partir de los años 2008 y 2011 dos casos de colusión afectaron la esfera de la libre competencia económica, ocasionado impacto en la opinión pública. Estos casos involucraron la participación de las empresas farmacéuticas Salcobrand, Cruz Verde y Fasa (Ahumada) en la fijación de precios de los medicamentos comercializados (o "Caso farmacias"), y la definición coordinada de un determinado nivel de producción de carne de pollo por parte de las mayores empresas avícolas del país (Agrosuper, Ariztía y Agrícola Don Pollo) y su asociación gremial (caso conocido como el "Cartel de los pollos"). Aunque ambas situaciones fueron objeto de juzgamiento por parte del Tribunal de Defensa de la Libre Competencia (en adelante

1 De hecho, el abuso de la posición dominante y las prácticas predatorias o de competencia desleal, como conductas contrarias a la libre competencia económica (en asocio con las prácticas colusivas), se encuentran consagradas en Chile en el artículo $3^{\circ}$ Decreto Ley ${ }^{\circ}{ }^{2} 11$, de 1973, modificado por el artículo $1^{\circ}$ Ley $n^{\circ} 20.945$ de 2016.

2 GONZÁlez et al. (2011) p. 143.

3 Artículo 3, letra a), Decreto Ley $n^{\circ} 211$, de 1973, modificado por artículo $1^{\circ}$ Ley n ${ }^{\circ} 20.945$ de 2016. 
TDLC), autoridad que impuso sendas multas en contra de las sociedades involucradas en estos hechos, la desproporción de los perjuicios ocasionados a los consumidores en comparación con las multas aplicadas y la falta de una sanción penal para castigar estas prácticas anticompetitivas reavivó la controversia sobre la necesidad de sancionar o no, dentro del marco del Derecho Penal, este tipo de conductas.

Posteriormente, un acuerdo que entra a formar parte de esta dinámica en materia colusiva, es el pacto llevado a cabo por las empresas CMPC y SCA para establecer altos precios durante más de 10 años en productos como el papel higiénico, toallas y pañuelos desechables, (caso conocido como "Cartel del Confort").

En este escenario y a fin de conocer el contenido y las causas de las variaciones en el tratamiento de la "colusión" dentro del ordenamiento jurídico interno, el presente Artículo aborda, desde una perspectiva histórico-jurídica, la evolución de la figura en estudio, dentro del marco normativo chileno. La investigación tiene como punto de partida la revisión de los orígenes del tratamiento de la colusión en el Derecho comparado, con énfasis en los Estados Unidos (teniendo en cuenta su influencia sobre el modelo chileno) y avanza, examinando la primera regulación en materia de libre competencia en Chile, consagrada en el Título $V$ de la Ley ${ }^{\circ}$ 13.305 de $1959^{4}$ (y el rol de la misión Klein-Saks), pasando por el Decreto Ley $n^{\circ} 211$ de 1973 (más conocido como "Ley antimonopolios"), las leyes $\mathrm{n}^{\mathrm{o}} 19.911^{5}$ del 2003 (que eliminó la colusión como tipo penal) y n ${ }^{0} 20.361$ de 2009, hasta llegar a la Ley $n^{\circ} 20.945$ de 2016 (en adelante, también puede ser denominada "Ley Antimonopolios"), la que incorpora sanciones penales ante conductas colusivas. El trabajo propuesto concluye con la realización de un análisis de la citada Ley $\mathrm{n}^{\circ} 20.945$, profundizando en el contenido y justificación de los mecanismos capaces de generar impacto en el combate de los acuerdos de naturaleza colusiva, incluyendo la

4 Así Felipe Irarrázabal Philippi en Seminario “Los Nuevos Desafíos de la Política de Competencia en Argentina: Balance de Diez Años de la Ley, Proyecciones e Instrumentos en Contextos Cambiantes", celebrado en Buenos Aires, Argentina, el 11 de junio de 2010, exponiendo sobre «El Sistema Chileno de Defensa de la Libre Competencia» (texto de la ponencia disponible en: http://www.fne.gob.cl/wp-content/uploads/2011/o5/OTRO_ooo1_2010.pdf, fecha de consulta: 20 abril 2017).

5 Historia de la Ley en: https://www.leychile.cl/Consulta/portada_hl?tipo_norma=XX1\&nro_ ley=19911, fecha de consulta 25 agosto 2017. 
criminalización de la colusión, el fortalecimiento de la delación compensada y el aumento del monto máximo de las multas.

\section{ANTECEDENTES DEL TRATAMIENTO DE LA COLUSIÓN: ORÍGENES EN EL ÁMBITO DEL DERECHO COMPARADO}

A nivel universal y dentro del marco económico, la tendencia de los empresarios a restringir la competencia y a coludirse para favorecer aumentos artificiales de precios son conductas que se reconocen a partir de la "Investigación sobre la naturaleza y las causas de la riqueza de las naciones" (1776) desarrollada por Adam Smith, trabajo conocido como "La riqueza de las naciones". ${ }^{6}$ Estas tendencias se confirman en el contexto de la llamada "Revolución industrial", que se desarrolló, primero, en Gran Bretaña y, después, en las regiones noroccidentales de Europa y en Estados Unidos, especialmente durante el siglo XIX.

En el país norteamericano los empresarios lograron llevar sus compañías a posiciones dominantes en el mercado a fines del siglo XIX acudiendo a la negociación de acuerdos colusivos (o carteles), entre otras conductas contrarias a la competencia. Esta situación comenzó a cambiar a partir de la promulgación en 17 Estados (a finales de la década de 1880) de leyes antimonopolio, en asociación con la creación, en el ámbito federal, de la Interstate Commerce Commision (1887), organismo a cargo de regular el tráfico ferroviario entre los Estados, transformación que se consolida con la publicación de la primera ley federal antimonopolios o Sherman Antitrust Act of 189o. Esta ley (que al inicio de su aplicación estuvo influenciada por el conflicto entre la normativa antitrust estatal y federal,, aspecto observable en sus primeras decisiones), ${ }^{8}$ prohibiría los contratos, la combinación

6 Puntualmente, en su obra el autor identifica esta tendencia al considerar que "rara vez se verán juntarse los de una misma profesión u oficio, aunque sea con motivo de diversión o de otro accidente extraordinario, que no concluyan sus juntas y sus conversaciones en alguna combinación o concierto contra el beneficio común, conviniéndose en levantar los precios de sus artefactos o mercaderías". Véase SMITH (1794) pp. 223-224.

7 Hovenkamp (2003) p. 7.

8 Influencia que se puede ver en casos de carteles como Trans-Missouri (1897) o Addyston Pipe (1899). Véase United States vs. Trans-Missouri FreightAss'n, 166 U. S. 290 (1897) y United States vs. Addyston Pipe \& Steef Co. 85 F 271 6th Cir.1898, aff'd, 175 U.S. 211 (1899). 
y las conspiraciones "para restringir el comercio", y la "monopolización" o conspirar para monopolizary, pese a no contener ninguna noción precisa acerca del significado exacto de "monopolio" o de las acciones que eran prohibidas, el significado fue aclarado, posteriormente, porvía jurisprudencial. ${ }^{9}$ La Sherman Act. sería después aclarada y reforzada por la Clayton Act of 1914 (estatuto que rechaza la discriminación de precios entre diferentes compradores de artículos de la misma clase y calidad, siempre que esta conducta sea capaz de reducir la competencia sustancialmente o generar un monopolio en cualquier línea del comercio), ${ }^{10}$ y fortalecida con el establecimiento en el mismo año de la Federal Trade Commission, organismo al que se le otorga la potestad de vigilar el correcto funcionamiento de la economía y la persecución ante cualquier infracción a la legislación antimonopolios, facultades que se ampliaron el año 1938 con la autorización para investigar y prohibir la publicidad falsa y engañosa."

\section{ANTECEDENTES DEL TRATAMIENTO DE LA COLUSIÓN DESDE UNA PERSPECTIVA HISTÓRICO JURÍDICA: DERECHO CHILENO Y EL TÍTULO V DE LA LEY No 13.305 DE 1959}

Concentrados en Chile, fue un grupo de economistas estadounidenses (conectados con el gobierno de Estados Unidos y el Fondo Monetario Internacional) conocido como la misión Klein-Saks quienes, entre los años 1955 y 1958 (por encargo del gobierno de Carlos Ibáñez) y con el objetivo de generar un plan de estabilización y de sentar nuevas bases para el crecimiento económico en el país formularon una serie de medidas de entre las cuales surgió la primera ley que aborda la temática de los monopolios o Ley $\mathrm{n}^{\mathrm{0}} 13.3 \mathrm{O} 5$ de $1959{ }^{12}$ antecedente normativo del Decreto Ley $\mathrm{n}^{\mathrm{O}} 211$ de 1973.

La aprobación de la Ley $\mathrm{n}^{0} 13.305$ estuvo precedida por el comportamiento pendular que caracterizó a la economía chilena entre las décadas de 1920 a 1950 del siglo XX. En efecto, al identificar cada una de las etapas

9 Samuelson y Nordhaus (2006) p. 341.

10 Samuelson y Nordhaus (2006) pp. 341-342.

11 Bernedo (2013) p. 28.

12 Carrasco (2009) pp. 428 y ss. 
dentro de este comportamiento económico interno, inicialmente hay un fuerte rol empresarial otorgado al Estado durante el primer gobierno de Carlos Ibáñez (1927-1931), situación que surge a la par con la promulgación de la Constitución de 1925 y el trabajo llevado a cabo por la Misión Kemmerer (1925).13 Posteriormente, transcurre el denominado Estado desarrollista dentro de la "Era radical" (1938-1952), época caracterizada por la presencia de un Estado con altos grados de intervención en la vida económica que, pese a los buenos resultados logrados en un principio, ${ }^{14}$ devino en un creciente fenómeno inflacionario. Finalmente, ante esta crisis, el Gobierno en 1955 contrató a una misión de expertos estadounidenses para que propusieran un plan de estabilización (Misión Klein \& Saks), ${ }^{15}$ de cuyas propuestas surge la Ley $\mathrm{n}^{0} 13.305$ de 1959 , que -puntualmente- en su Título V (vigente desde el 6 de abril de 1959 hasta el 22 de diciembre de 1973) consagraba una amplia legislación antimonopolios y sancionaba las prácticas restrictivas que pudieran afectar la libre competencia. ${ }^{16}$

Del Título V de la Ley $\mathrm{n}^{\circ} 13.305$ (denominado "Normas para fomentar la libre competencia industrial y comercial", y que incluía desde el artículo 172 al 182) interesa en particular el artículo 173, norma que impone -por primera vez-sanciones penales contra ciertas conductas que atacaban la libre competencia, ${ }^{17}$ algunas, claramente, de naturaleza colusiva, como los "convenios de fijación de precios o repartos de cuotas de producción, transporte o de distribución, o de zonas de mercados". A fin de cumplir lo establecido en el citado Título $\mathrm{V}$, la legislación contempló una entidad

13 A pesar de que la Misión prestó su asesoría en diversas áreas, es indiscutible que el rol con que se identifica en Chile fundamentalmente a Edwin Walter Kemmerer (quien, precisamente, encabezó estas Misión), es su participación en la creación del Banco Central. Véase CARrAsco (2009) p. 99.

14 A este respecto, a partir de 1939, Chile se distinguió por un consistente esfuerzo que apuntaba a la elaboración de planes de desarrollo sectorial y a la creación de empresas estatales y mixtas, que debían desempeñar un papel fundamental en el desarrollo económico nacional. Sobre esta base se puede afirmar que el modelo de economía mixta (basado en la sustitución de importaciones) que el país comenzó a estructurar a fines de la década de 1930, fue relativamente exitoso en materia de crecimiento logrando sortear los negativos efectos económicos de la Segunda Guerra Mundial. Véase Bernedo (2013) p. 32.

15 Carrasco (2009) p. 400.

16 BERnEDO (2013) pp. 29-39.

17 La parte final del artículo 173 establecía que quien realizara cualquiera de las conductas atentatorias contra la libre competencia descritas en la misma norma, sería "penado con presidio menor en cualquiera de sus grados y con multa de uno por ciento al diez por ciento del capital en giro de los autores". 
llamada "Comisión" (más conocida como "Comisión Antimonopolios"), encargada del estudio o resolución de todas las situaciones o hechos "que puedan dar lugar la aplicación de este Título y de las denuncias, reclamaciones, solicitudes o consultas que puedan formular las autoridades, las entidades públicas o privadas y los particulares sobre las mismas materias" $^{\prime \prime}{ }^{18}$ labor que debía cumplirse (según la propia jurisprudencia del organismo) con base en el principio según el cual "hay conveniencia pública en que el precio de los productos se fije por la libre competencia". ${ }^{19}$ Para apoyar el trabajo de esta "Comisión", se creó la figura de un Fiscal que dependía de la citada entidad. ${ }^{20}$

Enfocados en materias de carácter colusivo, pese a que la Comisión abordó el conocimiento de numerosas denuncias de dumping y de acuerdos de precios, ${ }^{21}$ estableciendo incluso cierta jurisprudencia en este ámbito, ${ }^{22} \mathrm{en}$ la práctica sólo en una vez dispuso el ejercicio de la acción penal (en otra ocasión, esta acción la dispuso la Corte Suprema), teniendo en cuenta que las conductas, que podían afectar la libre competencia, habitualmente eran sancionadas por medios diferentes a la represión penal. ${ }^{23}$

Finalmente, y precedida por la cada vez menor voluntad política de aplicar la ley en favor de la libre competencia (actitud presente durante los gobiernos de Eduardo Frei Montalva y Salvador Allende), tras el golpe de Estado de 1973 la Junta de Gobierno tramitó una nueva legislación antimonopolios, que inspirada en varios aspectos del Título $V$ de la ley $n^{0} 13.305$ se institucionalizó a través del Decreto Ley $\mathrm{n}^{0} 211$ del 22 de diciembre de 1973 (en adelante, "Ley Antimonopolios"), estatuto que fijó las denominadas "Normas para la Defensa de la Libre Competencia". ${ }^{24}$ En este contexto histórico, al Título $\mathrm{V}$ de la Ley $\mathrm{n}^{\mathrm{O}} 13.3 \mathrm{O} 5$ se le concede un doble rol: logra relevancia en el tiempo previo al inicio del régimen militar, al constituirse

18 Artículo 175, Ley no ${ }^{0} 3.305$, de 1959.

19 Resolución s/n del 23 de mayo de 196o, pp. 139-140.

20 Por la dificultad y el volumen de asuntos por resolver atribuidos a la "Comisión" se consideró necesario ampliarle sus facultades. A tal fin, se creó el cargo de fiscal (Ley ${ }^{\circ}{ }^{15.142}$, de 1963).

21 Ortúzar (1978) p. 127.

22 Por ejemplo, un fallo del 6 de abril de 196o sancionó el reparto de cuotas de producción entre los matarifes municipales de Santiago, y otro del 23 de marzo de 1960 ("Caso molineros") determinó que la fijación de precios por parte del Estado no impedía sancionar acuerdos de precios entre las empresas de un mismo rubro. 
en un instrumento eficaz para limitar las acciones de intervención económica del Estado ${ }^{25}$, y sirvió de inspiración para la estructuración de la nueva legislación de defensa de la libre competencia, iniciada inmediatamente después del golpe militar de septiembre de 1973.

\section{TRATAMIENTO DE LAS CONDUCTAS COLUSIVAS DENTRO DEL MARCO DE LA “LEY ANTIMONOPOLIOS”: PERÍODO DE 1973 A 1990}

Con base en el reconocimiento del Título $V$ de la Ley $n^{0} 13.305$ (como marco normativo de referencia en la construcción del Decreto Ley $n^{\circ} 211$ ), comprender los cambios en el tratamiento de las conductas colusorias, ocurridos a partir de septiembre del 1973 exige contrastar esta primera ley con la "Ley antimonopolios". Al respecto, en esta parte del Artículo se identifican las principales diferencias entre el Título $V$ de la Ley $n^{0} 13.305$ y el Decreto Ley $\mathrm{n}^{0}$ 211, con énfasis en el ámbito de la colusión, estudio enfocado en el período de tiempo trascurrido entre 1973 y 1990.

\section{Pilares que fundamentan a la "Ley Antimonopolios"}

Esta regulación, que surge en los inicios del régimen militar que gobernó a Chile entre los años 1973 a 1990, tiene su génesis en dos pilares fundamentales, uno de carácter programático y otro de carácter normativo. El pilar programático se genera dentro del ambiente de liberalización del mercado e impulso de la libre competencia, originado en las políticas económicas establecidas por el Gobierno a partir del golpe de Estado de 1973. A este respecto, con el objeto de superar la presencia de actividades monopólicas que dominaba el aparato productivo chileno (asociado al proteccionismo industrial y la interferencia del Gobierno a través de controles directos o de la legislación vigente hasta ese entonces), se optó por seguir con un programa basado en la apertura al comercio exterior, el aumento de la competencia y una decidida política antimonopolios. ${ }^{26}$

25 Centro de Estudios Públicos CeP (1997) pp. 75-77.

26 Estas pautas tienen su núcleo en un texto elaborado por un grupo de becarios chilenos que realizaron estudios de posgrado en economía en la Universidad de Chicago (grupo conocido 
El pilar normativo tiene en cuenta buena parte de los preceptos estipulados en el Título $V$ de la Ley $\mathrm{n}^{\mathrm{O}}$ 13.305. Precisamente, y como consecuencia de la liberalización de precios adoptada por el Ministerio de Economía después de septiembre de 1973, surgió la necesidad de establecer un marco legal antimonopolios, situación por la cual se recurrió a la estructura legal ya existente, es decir, al citado Título V. En este contexto, con la aplicación de las nuevas normas se pretendía que, al consolidarse la liberación de precios, los productores no pudieran seguir haciendo uso de sus posiciones monopólicas y rebajaran el valor de sus productos, factor asociado al efecto sicológico que se lograría (sobre todo entre los empresarios). ${ }^{27}$

\section{Principales diferencias entre el Título V de la Ley No 13.305 y la "Ley Antimonopolios"}

No obstante que la "Ley Antimonopolios" tiene su origen en el Título $\mathrm{V}$ de la Ley $\mathrm{n}^{0}{ }^{13.305}$, al contrastar estos textos legales es posible observar los mayores alcances otorgados aquella respecto de la normativa original, los que se concretan a partir del cumplimiento de las siguientes directrices: cobertura geográfica más amplia, un mayor poder de fiscalización, control y prevención, y más medios administrativos para desarrollar sus tareas. Esta ampliación en el rango de acción de la nueva institucionalidad incide en diversas materias, entre las que se incluye el tratamiento de las conductas de naturaleza colusiva. A continuación se analiza esta situación, enfatizando en lo concerniente a la colusión.

A) Dentro del marco estricto de la libre competencia, mientras que el Título $V$ de la Ley $\mathrm{n}^{\mathrm{O}} 13.305$ estaba dirigido únicamente a fijar las normas para "fomentar la libre competencia industrial y comercial" (según reza el encabezado de este Título V), la "Ley Antimonopolios" posee un mayor espectro de aplicación pues apunta a fijar las "normas para la defensa de la libre competencia" (según reza el título del estatuto antimonopolios). En este contexto, se nota que el Título V está limitado a "fomentar", ello a su vez restringido a: "la libre competencia industrial y comercial".

como los "Chicago Boys"). Véase Centro de Estudios Públicos (1992) pp. 7 y 47-48.

27 A la par con el aprovechamiento de la infraestructura normativa existente (Título $V$ de la Ley $\mathrm{n}^{\mathrm{0}}$ 13.305), se tuvo en cuenta la experticia que sobre el tema de la libre competencia tenía el fiscal antimonopolios de la época, el abogado Waldo Ortúzar, experiencia que sirvió para evaluar la operatividad de la legislación existente. Véase BERNEDo (2013) pp. 65-66. 
B) En el texto de la "Ley Antimonopolios" (a fin de promover "una sana y efectiva competencia en el abastecimiento de los mercados" ${ }^{28}$ se buscó otorgan de una mayor protección ya de los consumidores, filosofía que estaba acorde con la necesidad de mantener el apoyo de la ciudadanía ante la realidad política originada a partir del golpe de Estado.

C) Concentrados en el tratamiento de las conductas colusivas, aunque el Título $V$ de la Ley $\mathrm{n}^{0}{ }^{13.30}$ establecía sanciones privativas de la libertad para quienes cometieran ciertas conductas que afectaran la libre competencia, las mismas solo eran aplicables a los comportamientos expresamente estipulados en su artículo 173. La "Ley Antimonopolios" avanzó en este aspecto, manteniendo la sanción de presidio para quienes cometieran "cualquier hecho, acto o convención" que "tienden a impedir"29 la libre competencia (aumentando incluso la pena a quienes cometieran el delito en el ámbito de los bienes o servicios de primera necesidad), ${ }^{3 \circ}$ pero formulando un listado no taxativo de los delitos atentatorios contra la misma, dejando abierta la posibilidad de perseguir otras figuras delictivas que tuvieran como finalidad "eliminar, restringir o entorpecer la libre competencia" (el Título V solo consagraba la expresión "eliminar").31

Entre los comportamientos colusivos incluidos en la norma están los que podían afectar la producción, reparto de cuotas, sus reducciones o paralizaciones referidos al comercio o distribución, (v.gr., reparto de cuotas o la asignación de zonas de mercado o de distribución exclusiva por una sola persona o entidad de un mismo artículo de varios productores y referidos a la determinación de los precios de bienes y servicios v.gr. acuerdos o la imposición de los mismos a otros)..$^{22}$

28 En la Exposición de Motivos ( $\left.\mathrm{n}^{\circ}{ }_{1}\right)$ de la "Ley Antimonopolios" se lee que "el monopolio y las prácticas monopólicas son contrarias a una sana y efectiva competencia en el abastecimiento de los mercados, ya que mediante el control de la oferta o demanda es posible fijar precios artificiales y lesivos al interés del consumidor".

29 La expresión "tienden a impedir" tiene un carácter relevante, ya que por virtud de la misma y desde la perspectiva de la "Ley Antimonopolios", bastaba que un hecho o acto tuviese la intención de eliminar o entorpecer la libre competencia para proceder a castigarlo, sin que fuera una condición necesaria la verificación de un resultado concreto. Véase Ortúzar (1978) p. 132.

30 Texto original del artículo $1^{\circ}$ de la "Ley Antimonopolios".

31 Texto original del artículo $2^{\circ}$ letra e) de la "Ley Antimonopolios".

32 Texto original del artículo $2^{\circ}$, letras a), c) y d) de la "Ley Antimonopolios". 


\section{Organismos encargados del tratamiento de las conductas colusivas, desde la perspectiva de la "Ley antimonopolios"}

A fin de combatir eficazmente los conductas de naturaleza colusiva dentro del marco de fortalecimiento de la defensa de la libre competencia, la "Ley antimonopolios" configuró una nueva institucionalidad, más avanzada que la establecida en el Título $V$ de la Ley $n^{0} 13.305$. La nueva normativa determinó la creación de tres tipos de comisiones (a diferencia de lo ocurrido con el Título V, en la que solo existía una "Comisión", cuerpo insuficiente dado el volumen de asuntos a resolver) y fortaleció el rol del fiscal económico (concediéndole un alto grado de poder y autonomía funcionaria), en los siguientes términos:

A) En cuanto a las comisiones, y a la cabeza de la estructura institucional, se creó la denominada Comisión Resolutiva (con sede en Santiago), cuyas competencias incluían la supervigilancia en la aplicación de las normas de la "Ley antimonopolios" y el correcto desempeño de los organismos de su dependencia, ${ }^{33}$ asumiendo así una orientación más legal y actuando como tribunal; ${ }^{34}$ éste tenía capacidad para resolver y sancionar, y sus decisiones solo podían ser objeto de recurso de reclamación en casos puntuales ante la Corte Suprema, ${ }^{35}$ ampliándose sus facultades con el Decreto Ley $\mathrm{n}^{\circ}$ 2.760 de $1979 .{ }^{36}$ En segundo lugar, se crearon las Comisiones Preventivas Provinciales (ubicadas en las capitales de provincia del país, y que con el Decreto Ley $\mathrm{n}^{\mathrm{O}} 2.760$ asumieron el nombre de Comisiones Preventivas Regionales), cuyo rol era consultivo y preventivo respecto de situaciones que afectaran efectivamente o pudieran afectar a la libre competencia, ${ }^{37}$ organismos con propósitos parecidos a los de la Federal Trade Commission de los Estados Unidos (FTC). ${ }^{38} Y$ con las mismas atribuciones que las Comisiones Preventivas Provinciales, pero con competencia nacional,

33 Texto original del artículo 17 de la "Ley Antimonopolios".

34 Este organismo entonces realiza las acciones que corresponden al Departamento de Justicia de los E.U. Véase Paredes (1995) p. 233.

35 Texto original del Artículo 19 de la "Ley Antimonopolios".

36 El Decreto Ley $\mathrm{n}^{\circ} 2.760$, del 5 de julio de 1979, generó ajustes en la institucionalidad de la libre competencia, tanto en su parte orgánica (aumentando las plantas de personal) como operativa, otorgando mayor poder a estos miembros, en particular, al que a partir de esta normativa se denominaría como Fiscal Especial.

37 Texto original del Artículo 8 de la "Ley Antimonopolios".

38 Es decir, posee una estructuración que la hace más analítica. 
se creó la Comisión Preventiva Central. ${ }^{39}$ Sin embargo, una circunstancia generó cierta debilidad operativa en la labor de estos organismos: el trabajo de los distintos comisionados era ad honorem, factor que obedeció a que en el momento de su creación (finales de 1973) la realidad política chilena exigía reducir el aparato Estatal y sus gastos.

B) A diferencia de la debilidad atribuida a las comisiones, se evidenció un fortalecimiento del poder y la autonomía por parte del fiscal económico. Es en este contexto que se crea como un organismo público independiente la denominada Fiscalía de la Defensa de la Libre Competencia (la cual a partir del Decreto Ley $\mathrm{n}^{0} 2.760$ se denominó Fiscalía Nacional Económica o FNE), unidad que se encontraba encabezada por un fiscal (apoyado por una planta de personal), ${ }^{\circ}$ cuyo objetivo era el de asistir a las comisiones, apoyarlas administrativamente, servir de organismo ejecutor de lo que éstas acordaran y, sobre todo, investigar y acusar, funciones que según la propia "Ley antimonopolios" podía ejercer el fiscal con total independencia "de todas las autoridades o tribunales ante los cuales es llamado a ejercerlas", atribución que le permitía a éste "defender los intereses que le están encomendados en la forma que estime arreglada a Derecho, según sus propias apreciaciones". ${ }^{41}$ La labor del Fiscal Nacional era apoyada por los fiscales delegados designados en cada capital de provincia, los cuales dependían del primero. ${ }^{42}$

\section{Jurisprudencia en materia de conductas colusivas, desde la perspectiva de la "Ley antimonopolios".}

Dentro del ámbito de la protección de la libre competencia en materia económica, el trabajo mancomunado efectuado por la institucionalidad antimonopolios se centró en la investigación (por parte de la FNE) y el tratamiento e interpretación (por parte de las Comisiones Antimonopolios) de cuatro asuntos: discriminación de precios, fijación de precios de reventa, distribución exclusiva y acuerdos horizontales de precios. ${ }^{43}$ Los

39 Artículo 11 original de la "Ley Antimonopolios".

40 Artículo 23 original de la "Ley Antimonopolios".

41 Artículo 24 original de la "Ley Antimonopolios".

42 Artículo 22 original de la "Ley Antimonopolios".

43 Sobre el particulary para tener en cuenta, Paredes (1995) pp. 244-265, quien analiza la jurisprudencia de las Comisiones Antimonopolios respecto de las cuatro conductas citadas (juris- 
casos en los cuales surgen estos temas se concentran en los primeros años de funcionamiento de la nueva institucionalidad antimonopolios, época en la que se fue generando la jurisprudencia y la entrega de la información de lo que era y no era legal dentro del marco en estudio.

Enfocado en las manifestaciones colusivas, se deben tener en cuenta los acuerdos horizontales de precios, cuya calificación como prácticas anticompetitivas está fundada en que, al decidir actuar coordinadamente, los productores pueden comportarse como un auténtico monopolio. En este sentido, la consecuencia del acuerdo será un precio mayor que el precio de competencia a través de la supresión de un aspecto de ella. ${ }^{44}$ La herramienta mayormente utilizada por la institucionalidad antimonopolios para determinar la existencia de acuerdos de precio consistió en el uso extensivo de las encuestas de precios, subrayando que si en ellas se verificaba uniformidad de precios entonces se presumía la existencia de un acuerdo. ${ }^{45}$

Continuando con el estudio de los acuerdos horizontales de precios, puede hablarse de una relativa consistencia por parte de los organismos antimonopolios al reprimirlos. Sin embargo, no siempre existió un criterio unánime en este ámbito. Al respecto, debe tenerse en cuenta diversas decisiones emitidas por las Comisiones Antimonopolios, destacándose las siguientes:

A) La decisión originada en la consulta formulada por el Colegio de Ingenieros de Chile acerca de la legitimidad de acordar un honorario mínimo por sus servicios, sobre lo cual la Comisión Resolutiva determinó que la fijación de este tipo de ingresos por los colegios profesionales no era un acto comprendido dentro del campo de aplicación de la "Ley antimonopolios", se estimó que el trabajo humano no debe ser considerado como una mercancía y, por lo tanto, su valor no debe quedar sujeto a las leyes del mercado. ${ }^{46}$

B) Las discrepancias originadas en los criterios establecidos por las Comisiones Preventiva y Resolutiva. Para destacar, se observa un caso que involucró

prudencia generada entre 1973 a 1994) y que este autor considera como las más significativas, conductas investigadas por la FNE y tratadas por las Comisiones Antimonopolios.

Paredes (1995) p. 260.

46 Comisión Resolutiva, Resolución nº 6, de 1974. 
a los dos principales laboratorios farmacéuticos de Chile en ese momento (Laboratorios Chile y Recalcine), asunto fundado en diversos antecedentes que decían relación con el nivel y movimiento idéntico de precios en esa industria, con la caída en el porcentaje del mercado de estos laboratorios y el aumento de ese mismo porcentaje respecto a los competidores, y a que el verificado aumento de los precios se había constatado en la misma fecha en la que entró a operar un contrato entre los citados laboratorios (circunstancia esta última que facilitaba la vigilancia de cuotas pre-establecidas). ${ }^{47}$ En concreto, mientras que la Comisión Preventiva recomendó sanciones por acuerdo de precios a partir de los datos mencionados (los que, conceptualmente, eran acordes con la hipótesis de que existía colusión), la Comisión Resolutiva dejó sin efecto el Dictamen anterior por considerar necesaria la práctica de pruebas que acreditaran los hechos.

\section{FORTALECIMIENTO DEL SISTEMA DE DEFENSA DE LA LIBRE COMPETENCIA Y SUS CONSECUENCIAS EN EL TRATAMIENTO DE LAS CONDUCTAS COLUSIVAS: SUPRESIÓN DE SU CARÁCTER PENAL}

Desde una perspectiva histórica y transcurridas las décadas de 1970 y 1980 (caracterizadas por la reducción del rol interventor del Estado en el campo económico y el impulso del libre mercado con base en la participación activa de los agentes privados), a partir de los años noventa el mundo empresarial comenzó a compartir su protagonismo con un universo masivo de consumidores..$^{8}$ En este escenario y como uno de los temas a tratar dentro una política más amplia del gobierno de Eduardo Frei Ruiz-Tagle (1994-2000), ${ }^{49}$ se buscó perfeccionar la institucionalidad de la defensa de la libre competencia, diagnosticándose que los principales problemas que enfrentaban las tres instancias que la integraban (Comisiones Preventivas, Comisión Resolutiva y FNE) se referían a su debilidad técnica y presupuestaria..$^{\circ}$

47 Comisión Preventiva, Dictamen no 818, de 1992 y Comisión Resolutiva, Resolución nº 397, de 1993.

48 TiRONI (1999) p. 227.

49 Política impulsada por la "Comisión Jadresic".

50 BeRnedo (2013) p. 144. 
Como consecuencia del diagnóstico anterior, el proceso para robustecer la defensa de la libre competencia se desarrolló de manera gradual, iniciándose formalmente con la promulgación de la Ley $\mathrm{n}^{0} 19.610$ de 19 de mayo de 1999, que otorgó a la FNE mayor capacidad operativa en su rol investigador pero que generó una suerte de desequilibrio institucional con las Comisiones al no fortalecer el rol y las capacidades de éstas, circunstancia que fue objeto de críticas en su momento. ${ }^{51}$

Es en este ambiente (y a fin de cumplir con la gradualidad en el proceso de mejoramiento de la institucionalidad en materia de defensa de la libre competencia), se presenta un hito que afectó directamente el tratamiento de las conductas colusivas, particularmente en lo que concierne a las sanciones a imponer ante estos comportamientos anticompetitivos, la publicación de la Ley $\mathrm{n}^{0} 19.911$ de 14 de noviembre de 2003, que creó el Tribunal de Defensa de la Libre Competencia (o TDLC). Esta ley generó cambios en diferentes materias, entre las que se cuentan el de las sanciones (incluyendo la supresión del carácter penal), la estructura y las funciones de la nueva institucionalidad, el establecimiento de conductas anticompetitivas concretas y el aumento del estándar probatorio para la FNE. A continuación, se revisan estos cambios, con énfasis en lo relativo a las sanciones.

\section{Modificación a la "Ley antimonopolios" en el ámbito de las sanciones}

La Ley $\mathrm{n}^{0} 19.911$ suprimió el castigo penal frente a conductas contrarias a la libre competencia dejando solamente sanciones de naturaleza administrativa. En contraprestación a este cambio se incrementaron los montos máximos de las multas de 10.000 a 20.000 mil unidades tributarias anuales (en adelante UTA), ${ }^{22}$ estableciéndose como criterios para fijar la cuantía, los siguientes: el beneficio económico obtenido con motivo de la infracción, la gravedad de la conducta y la calidad de reincidente del contraventor. ${ }^{53}$

Las justificaciones de esta modificación en la naturaleza de la sanción impuesta, obedece a varias causas, incluyéndose aspectos relativos al

51 En general, las críticas apuntaban a que la Ley $\mathrm{n}^{0}$ 19.610, de 1999, no había efectuado modificaciones en relación a la integración de las comisiones, sus grados de autonomía respecto del Poder Ejecutivo y la profesionalización de sus miembros. Véase BeRNEDo (2013) p. 149.

53 Parte final, letra c), artículo 17 k Ley n ${ }^{\circ}$ 19.911, de 2003. 
grado de eficacia e idoneidad del tipo penal y la experiencia en el Derecho comparado. Dependiendo de la perspectiva estudiada, el motivo de los cambios en el ámbito de las sanciones se explican en las siguientes razones:

A) Desde la perspectiva doctrinal, Patricio Bernedo ${ }^{54}$, como explica y subraya las sanciones de tipo criminal no se habían utilizado, sobre todo debido a que los estándares probatorios para aplicar una pena privativa de libertad eran altamente exigentes.

B) Dentro del mensaje presidencial que propuso la derogación de las normas que planteaban una arista criminal para los ilícitos anticompetitivos, se plantearon como razones para la eliminación del carácter penal, de una parte, la falta de especificación de las conductas anticompetitivas (lo cual no cumpliría con los estándares exigidos por el artículo $19 \mathrm{n}^{\circ}$ 3 de la Carta Política) y, de otra, la estimación de que la criminalización no habría sido una medida idónea para disuadir las conductas contra la libre competencia. ${ }^{55}$

C) A partir de opiniones surgidas dentro del proceso de construcción de la Ley $n^{\circ} 19.911$, la supresión de las sanciones penales y el aumento de las multas se justificó en que los tipos penales eran incompatibles con el complejo escenario en que se desenvuelven los agentes económicos $y$, por otro lado, la experiencia internacional sobre la materia aconsejaba que cada situación debía ser estudiado en su propio mérito, de acuerdo con sus particularidades y complejidades, estimándose procedente establecer una norma amplia con ejemplos básicos (para que los integrantes del TDLC decidieran en cada caso qué conducta constituye un atentado a la libre competencia). Conforme a estos pareceres, se estimó que el aumento de las multas y el hacer solidariamente responsables de su pago a los directores, gerentes o administradores de las empresas infractoras, se constituiría en un mecanismo de disuasión más eficaz respecto de los potenciales trasgresores. ${ }^{5}$

54 Bernedo (2013) p.164.

55 Véase Historia de la Ley $\mathrm{N}^{\circ}$ 19.911, p. 12 (ver nota 5).

56 Véase Historia de la Ley $N^{\circ}$ 19.911, p. 32 (ver nota 5). 
D) Una causa adicional de la supresión de la sanción penal, la que solo se evidenciaría con la ocurrencia de los dos grandes acuerdos colusorios denominados "Caso farmacias" y "Cartel de los pollos" (los que se revisan en extenso a continuación), consiste en la ausencia de una conciencia acerca de la gravedad de estos ilícitos. ${ }^{57}$

\section{Estructura y funciones de la nueva institucionalidad}

Desde el punto de vista de la estructura y las funciones de la nueva institucionalidad, la normativa permitió construir un sistema dual, en el que las Comisiones Preventivas Regionales, Preventiva Central y Resolutiva fueron reemplazadas por el TDLC y a la FNE se le redefinieron sus funciones y atribuciones. En este sentido, al TDLC se le concedió el carácter de órgano jurisdiccional especial e independiente, ${ }^{58}$ sujeto a la superintendencia directiva, correccional y económica de la Corte Suprema, atribuyéndole las funciones de prevenir, corregiry sancionar los atentados a la libre competencia. ${ }^{59}$ La FNE quedó a cargo de la investigación y la presentación de requerimientos ante el TDLC, asumiendo el rol de servicio especializado en la instrucción de investigaciones de atentados a la libre competencia.

\section{Establecimiento de conductas anticompetitivas concretas}

A diferencia de lo estipulado en la "Ley antimonopolios", en la que se formulaba un listado no taxativo de conductas que podían atentar contra la libre competencia, la Ley $\mathrm{n}^{0} 19.911$ estableció un conjunto de conductas anticompetitivas concretas, enfocadas en los acuerdos colusorios, abusos de posición dominante, prácticas predatorias y competencia desleal, realizadas con el objetivo de alcanzar, mantener o incrementar una posición de dominio. ${ }^{60}$

57 Esta situación se reconoce en el Proyecto de ley que fija normas para la defensa de la libre competencia (Boletín $\mathrm{n}^{\circ}$ 9.950-03), iniciativa formulada el 2015 y que se convertiría en la Ley $\mathrm{n}^{\circ}$ 20.945 del 2016.

58 Organismo que por ese carácter de tribunal jurisdiccional, estaba facultado para actuar solamente a través de la presentación de un requerimiento de la FNE o de la demanda de un particular.

59 Artículo $7^{\circ}$ Ley ${ }^{\circ} 19.911$ del 2003.

60 BeRnedo (2013) p. 164. 


\section{Aumento del estándar probatorio para la FNE}

Finalmente, y a consecuencia de la creación del TDLC, aumentó el estándar probatorio exigido a la FNE a fin de respaldar sus requerimientos. Esta situación generó que varios casos relevantes impulsados por el organismo investigador no prosperaran, ${ }^{61}$ estableciéndose la necesidad de otorgar a la fiscalía mayores mecanismos para indagar casos de colusión, herramientas que se materializaron con la aprobación de la Ley $\mathrm{n}^{0} 20.361$ de 7 de julio de 2009 .

\section{CASOS “FARMACIAS" Y “CARTEL DE LOS POLLOS": EFECTOS EN EL TRATAMIENTO DE LAS CONDUCTAS COLUSIVAS DENTRO DEL ÁMBITO ECONÓMICO}

A partir de los años 2008 y 2011, dos casos de colusión afectaron la esfera de la libre competencia económica, ocasionando impacto en la opinión pública, en ellos participaron las empresas farmacéuticas Salcobrand, Cruz Verde y Fasa (Ahumada) fijando precios a los medicamentos comercializados ("Caso farmacias") y definieron coordinadamente un determinado nivel de producción de carne de pollo de las empresas avícolas Agrosuper, Ariztía y Agrícola Don Pollo y su asociación gremial (caso "Cartel de los pollos"). Aunque éstos no fueron los únicos casos de relevancia generados a partir de la creación del TDLC, ${ }^{62}$ su ocurrencia sí afectó el espectro normativo, planteando una discusión sobre la necesidad de restablecer o no las sanciones penales a fin de castigar estas conductas contrarias a la libre competencia. El contenido de esta discusión constituye la génesis de la Ley $\mathrm{N}^{\circ} 20.945$ de 2016 que perfecciona el sistema

61 En este marco, entre los casos relevantes iniciados por la FNE que no prosperaron, destacamos el desarrollado dentro del mercado de los combustibles líquidos contra Copec, Esso, Shell e YPF, entre otros.

62 Otro caso relevante lo representa la denominada "Guerra del plasma". En lo central, este caso (que fue objeto de sanción contra los denunciados por parte del TDLC, en Sentencia proferida en abril del 2008) se originó en el requerimiento formulado en agosto de 2006 por la FNE, requerimiento presentado en contra de las tiendas por departamento Falabella y Paris, por su acción concertada para hacer fracasar el evento "Feria Tecnológica" que el Banco de Chile había desarrollado como fidelización para sus clientes y promoción de sus tarjetas de crédito. Véase Fiscalía Nacional Económica (2010) p. 17. 
de defensa de la libre competencia, texto legal que incorpora sanciones penales ante conductas colusivas. ${ }^{63}$

A continuación se explican las características y efectos directos de estos dos casos emblemáticos, lo que permitirá entender las causas que dieron origen a la citada Ley $\mathrm{N}^{\circ} 20.945$ y efectuar un análisis de dicha normativa, con énfasis en los mecanismos capaces de generar efecto en el combate de los acuerdos de naturaleza colusiva.

\section{Características del "Caso farmacias"}

En lo que atañe a las conductas colusivas, es el "Caso farmacias" el que posee un mayor grado de incidencia en este ámbito de la economía. La historia de este acuerdo se desarrolló una ante el TDLC y ante la jurisdicción penal, dentro de los siguientes hitos:

A) En diciembre de 2008 la FNE demandó a las tres principales empresas farmacéuticas chilenas por colusión de precios de 220 medicamentos, ${ }^{64}$ acuerdo que derivó en el aumento del valor de las medicinas incluso más allá del 100\% (según estableció la misma FNE).

B) En marzo de 2009 se firmó una conciliación con Farmacias Ahumada, lo que implicó una multa por un millón de dólares. ${ }^{65}$

C) A inicios del año 2012 el TDLC impuso a las empresas Salcobrand y Cruz Verde una multa por 20.00o UTA a cada una (la máxima sanción dineraria permitida en su momento), decisión confirmada por la Corte Suprema. ${ }^{66}$

63 Ley publicada el 30 de agosto del 2016.

64 Situación ocurrida entre diciembre de 2007 y abril de 2008.

65 Véase en Diario LA TERCERA, 9 marzo 2015, "Revisa las claves del caso de colusión de precios en las farmacias".

66 Portal de noticias FNE: «Corte Suprema confirma sentencia del TDLC y aplica multa máxima a Farmacias Cruz Verde S.A. y Salcobrand S.A. por caso colusión» (disponible en: http://www. fne.gob.cl/2012/og/o7/corte-suprema-confirma-sentencia-del-tdlc-y-aplica-multa-maxima-a-farmacias-cruz-verde-s-a-y-salcobrand-s-a-por-caso-colusion/, fecha de consulta: 15 octubre 2015). 
D) En el juicio llevado a cabo entre el 6 de marzo y el 23 de junio de 2015 ante el Cuarto Tribunal Oral en lo Penal de Santiago los jueces absolvieron a los diez ejecutivos acusados vinculados a las empresas farmacéuticas. ${ }^{67}$

En lo central, los fiscales del Ministerio Público para acusar las responsabilidades personales detrás del pacto colusorio se basaron en el artículo 285 del Código Penal, que castiga a los que por medios fraudulentos consiguieren alterar el precio natural del trabajo, de los géneros o mercaderías, acciones, rentas públicas o privadas o de cualesquiera otras cosas que fueren objetos de contratación" (el destacado es nuestro). Sin embargo, y pese a no disentir mayormente sobre los hechos invocados por los fiscales en la acción penal, la mayoría de los jueces estimó que las conductas no se ajustaron a lo establecido por el antes dicho artículo 285, siendo precisamente el carácter fraudulento el elemento que los representantes del Ministerio Público no pudieron demostrar, en un ámbito penal donde el estándar de prueba es más exigente que el de la libre competencia. ${ }^{68}$

En el contexto anterior, en lo que toca a la acreditación del carácter fraudulento de las conductas atribuidas a los acusados dentro del proceso, varios de los correos presentados como prueba tenían como concepto genérico la "coordinación" para alzar los precios de los medicamentos. Sin embargo, según el Tribunal (con base en lo determinado por el Diccionario de la Real Academia Española) el vocablo "coordinar" debía entenderse como "disponer cosas metódicamente", 69 perspectiva bajo la cual los jueces interpretaron que el comportamiento a que aludían los emisarios de los correos a sus destinatarios (y a los que se les enviaba copia de los mismos) era el de "disponer alzar metódicamente los precios de los medicamentos, de lo que se desprende que el medio para llevar a la práctica el alza de precios sería la coordinación",70 agregándose en la sentencia que esta "coordinación" solamente puede tener efectos pena-

67 Para desarrollar este punto se tiene en cuenta el texto de la Sentencia del 28 de julio del 2015, identificada como Causa Rol n ${ }^{\circ}$ 531-2014 y proferida por el Cuarto Tribunal Oral en lo Penal de Santiago.

68 Sobre el particulary para tener en cuenta, HERNÁNDEZ (2012) pp. 147-167, quien aborda la cuestión de la posible relevancia jurídico-penal de la conducta de colusión (secreta) de precios entre oferentes de bienes y servicios, a la luz de los artículos 285 y 286 del Código Penal, de 1874, a partir del concepto de "medio fraudulento".

69 Sin embargo, la segunda acepción del concepto "coordinar" estipulado en el DRAE, es "concertar medios, esfuerzos, etc., para una acción común".

70 Belloniy otros (2014) Considerando 33. 
les cuando es "fraudulenta, lo que significa engañosa, falaz, calificativo que no es posible atribuirle a la acción de coordinar a la que aluden los correos electrónicos referidos, al no desprenderse de pruebas rendidas en el juicio".7י Sobre esta arista del "Caso farmacias" es pertinente señalar que las opiniones respecto al contenido de la sentencia giraron en torno a la necesidad de tipificar como delito las prácticas colusivas, teniendo en cuenta el hecho de que otras conductas con un impacto social y económico menor, sí estaban sancionadas por la legislación penal. ${ }^{72}$

\section{Efectos del "Caso farmacias"}

En el tratamiento de las conductas colusivas y desde el punto de vista de los asuntos en estudio, se reitera que el "Caso de las farmacias" es el que posee un mayor impacto en este ámbito de la economía. La anterior consideración tiene en cuenta los efectos generados con la ocurrencia de los comportamientos atribuidos a las empresas farmacéuticas, consecuencias que se manifiestan en dos hechos: a) la promulgación el 7 de julio de 2009 de la Ley $n^{\circ} 20.361$, norma encargada de perfeccionar el funcionamiento del TDLC, de conceder nuevas atribuciones a la FNE y de reforzar los procedimientos para investigar y sancionar las violaciones contra la libre competencia; b) el descontento ocasionado en la opinión pública con lo ocurrido (particularmente, el desenlace en lo penal) y las consecuentes críticas formuladas por distintos sectores de la sociedad, circunstancia ligada a la posterior presentación de sendas iniciativas legislativas. A continuación, se sistematizan los efectos del "Caso farmacias".

\section{A) Promulgación de la Ley nº 20.361 el 7 de julio de 2009}

No obstante que a partir de la creación del TDLC, y ante el aumento del estándar probatorio exigido a la FNE, se había sostenido la necesidad de otorgar mayores herramientas a este organismo a fin de investigar las conductas colusivas, del "Caso farmacias" generó un impulso para acelerar la aprobación de la Ley $\mathrm{n}^{0}$ 20.361. Esta normativa (además de afinar las

71 Belloniyotros (2014) Considerando 35.

72 Algunas opiniones en este sentido, fueron las expresadas por el abogado Jaime Retamal (uno de los fiscales dentro del caso), y por el ministro de economía Luis Felipe Céspedes. Véase en Diario El Mostrador (Chile), 24 junio 2015, "Artículo penal que no se actualiza hace más de 140 años fue la clave tras la absolución del caso Farmacias". 
competencias otorgadas originalmente al TDLC en la Ley $\left.n^{0} 19.911\right)$ fortaleció las facultades de la FNE para detectar acuerdos colusorios, otorgándole al organismo (previa autorización de Ministro de Corte de Apelaciones) la facultad de solicitar a Carabineros o a la Policía de Investigaciones (bajo la dirección de un funcionario de la FNE) el desarrollo de actuaciones de ingreso, allanamiento, registro, incautación e interceptación. ${ }^{73}$ Otro aspecto que incidió directamente en el tratamiento de los acuerdos colusivos fue el aumento de las multas hasta por una suma equivalente a 30.00o UTA, ante la ocurrencia de comportamientos violatorios de la libre competencia. ${ }^{74}$ Finalmente, la Ley $n^{0}$ 20.361, a fin de combatir más eficazmente la colusión en el plano económico, estableció la "auto-denuncia" o "delación compensada"75 y, aunque el mecanismo no es denominado de esta forma en el texto, la norma permitía que los involucrados en este tipo de conductas pudiesen acceder a una reducción o exención de la multa, siempre que aportaran a la FNE antecedentes que condujeran a la acreditación de dicho comportamiento y a la determinación de los responsables. ${ }^{6}$

B) "Caso farmacias" y su efecto en la promulgación de la Ley n²0.945 de 2016.

A demás de la aprobación de la Ley n² 20.361, el "Caso farmacias" generó una reacción en la ciudadanía y en diversos agentes políticos, que se reflejó en la opinión de que era necesario castigar con sanciones más gravosas estas conductas contrarias a la libre competencia; La ciudadanía expresó su descontento con declaraciones de rechazo de varias organizaciones

73 Artículo $1^{\circ}$, numeral 17, letra f), Ley $\mathrm{n}^{\circ}$ 20.361, del 2009, que modificó el artículo 39 del Decreto Ley $\mathrm{n}^{\circ} 211$, de 1973.

74 Artículo $1^{\circ}$, numeral 13, letra a), Ley $\mathrm{n}^{\circ}$ 20.361, del 2009, que modificó el artículo 26 del Decreto Ley $\mathrm{n}^{\circ} 211$, de 1973.

75 Portal de noticias FNE: «Fiscalía Nacional Económica extiende hasta el 28 de febrero consulta pública sobre nueva Guía de Delación Compensada» (30 enero 2015) (noticia disponible en: http://www.fne.gob.cl/fiscalia-nacional-economica-extiende-hasta-el-28-de-febrero-consulta-publica-sobre-nueva-guia-de-delacion-compensada-2/, fecha de consulta: 20 agosto 2017; «FNE pone en consulta pública segundo borrador de la nueva Guía de Delación Compensada» (20 octubre 2015) (noticia disponible en: http://www.fne.gob.cl/fne-pone-en-consulta-publica-segundo-borrador-de-la-nueva-guia-de-delacion-compensada/, fecha de consulta 20 agosto 2017.

76 Artículo $1^{\circ}$, numeral 18, Ley $n^{\circ} 20.361$ del 2009, que agregó el artículo 39 bis al Decreto Ley n ${ }^{\circ}$ 211 de 1973. 
ciudadanas,, 77 con demandas colectivas, ${ }^{78}$ con llamados al boicot contra las farmacias ${ }^{79} \mathrm{e}$, incluso, ataques a sucursales. ${ }^{80}$

A su vez, está la respuesta formulada por los agentes políticos durante los procesos llevados a cabo por el TDLC y por los jueces penales, reacción que no solo se planteó en declaraciones de rechazo ${ }^{81}$ sino que, más importante, se concretó con la presentación de un proyecto de ley por parte del Poder Ejecutivo al Congreso, iniciativa cuyo objetivo central consistió en restablecer las penas de cárcel a fin de sancionar los casos de colusión en el ámbito económico. El contenido de esta propuesta (identificada en su momento como Boletín $\mathrm{N}^{\circ}$ 9950-03), se materializó con la promulgación el 19 de agosto de 2016 de la Ley $\mathrm{N}^{\circ} 20.945^{82}$, la que se examinará en la parte final del presente Artículo.

\section{Características del caso "Cartel de los pollos"}

A diferencia de los acuerdos colusorios atribuidos a las farmacéuticas, las conductas llevadas a cabo por las mayores empresas avícolas del país (Agrosuper, Ariztía y Agrícola Don Pollo) y su asociación gremial (APA) fueron objeto de sanción exclusivamente dentro del marco de las normas de la libre competencia. En lo medular, ${ }^{83}$ el TDLC (previo requerimiento

77 Por ejemplo, la CONFUSAM calificó la colusión de farmacias como "un robo descarado y un crimen de lesa humanidad". Véase en Diario LA TERCERA (Chile), 14 abril 2009, "Confusam califica fallo en caso farmacias como "un insulto a la conciencia nacional"".

78 Como ejemplos, las demandas colectivas interpuestas por la corporación "Chilenos en Acción" y por el portal de soluciones jurídicas www.problemas.cl.

79 Por ejemplo, el alcalde de Pudahuel, Johnny Carrasco, llamó a boicotear por dos semanas a las farmacias coludidas, argumentando que esos establecimientos deberían recibir un castigo de parte de los consumidores. Véase en Diario LA TERCERA (Chile), 29 marzo 2009, "Alcalde de Pudahuel Ilama a boicotear las farmacias".

80 Véase en Diario LA NACIÓN (Chile), 27 marzo 2009, "Protestas contra farmacias: gobierno advierte "límite"".

81 La propia presidenta Michelle Bachelet, durante su Cuenta Pública del año 2009, calificó el "Caso farmacias" como un episodio "indignante", el cual graficaba la necesidad de tener un Estado que regulara y protegiera a la ciudadanía. Véase en Diario LA NACIÓN (Chile), 22 mayo 2009, "Con pena de cárcel castigarán el delito de colusión".

82 Historia de la Ley en: https://www.bcn.cl/historiadelaley/nc/historia-de-la-ley/5311/, fecha de consulta: 20 agosto 2017.

83 Para desarrollar este punto relativo a las características y efectos del caso "Cartel de los pollos", se tiene en cuenta el texto de la Sentencia del 25 de septiembre del 2014, N I39/2014 y proferida por el TDLC. 
formulado por la FNE) mediante sentencia del 25 de septiembre de 2014 impuso sendas multas a beneficio fiscal por un valor total de 72.000 UTA $^{84}$ y ordenó disolver la asociación gremial. Para aplicar estas sanciones el Tribunal tuvo en cuenta que,al menos durante una década, las empresas investigadas ejecutaron un acuerdo para limitar la producción de carne de pollo, controlando su cantidad y oferta al mercado nacional, asignando cuotas en el mercado de producción y comercialización de dicha carne.

\section{Efectos del caso "Cartel de los pollos"}

En cuanto a este acuerdo, se identifican dos efectos, el primero de ellos está basado directamente en el contenido de la sentencia en septiembre de 2014 por el TDLC y el segundo tiene que ver con el grado de reparación alcanzado con el fallo respecto de los consumidores afectados con la colusión. A continuación, se explican estos efectos.

A) Caso "Cartel de los pollos" y el contenido del fallo emitido por el TDLC

En la sentencia del TDLC se destacan la aplicación de dos medidas inéditas dentro del marco de la defensa de libre competencia; En uno, el Tribunal impuso, por primera vez, multas ajustadas al tope máximo contemplado en la legislación, ${ }^{85}$ condenando a las empresas Agrosuper y Ariztía al pago de 30.000 UTA cada una ${ }^{86}$ y, dos, a petición de la FNE, el TDLC ordenó la disolución de la asociación que agrupa a las empresas avícolas demandadas, gremio que coordinó el funcionamiento del cartel. ${ }^{87}$ Pero, pese al monto alcanzado por las multas aplicadas y la orden de disolución de la APA (con opinión favorable respecto al contenido de este fallo del TDLC), ${ }^{88}$

84 De este monto, Agrosupery Ariztía fueron condenadas a pagar zo.ooo UTA cada una, y Agrícola Don Pollo 12.00o UTA.

85 Recuérdese que la Ley $\mathrm{n}^{\circ} 20.361$ del 2009 estableció este tope máximo a las multas que debían imponerse en los casos de colusión.

86 Tribunal de Defensa de la Libre Competencia, Contra Agrícola Agrosuper S.A y otros (2014, $\mathrm{n}^{\circ}$ 139/2014), Parte Resolutiva, 3) y 4).

87 Tribunal de Defensa de la Libre Competencia, Contra Agrícola Agrosuper S.A y otros (2014, $\mathrm{n}^{\circ}$ 139/2014), Parte Resolutiva, 6).

88 Por ejemplo, el propio Fiscal nacional económico, Felipe Irarrázabal, declaró que "estamos enormemente satisfechos con la sentencia del TDLC", teniendo en cuenta que, a juicio de la FNE, éste había sido "el cartel más grande que el sistema de libre competencia haya tratado de desbaratar en Chile, desde su creación en 1959". Véase nota 92. 
se evidenció una desproporción al contrastar el daño ocasionado a los consumidores y la cuantía de dichas multas. A partir de esta desproporción (como uno de los elementos que justificaron el fortalecimiento de los instrumentos para combatir las conductas colusivas), a continuación se trata acerca de las reacciones ante el grado de reparación alcanzado con la sentencia en estudio.

B) Caso "Cartel de los pollos" y el grado de reparación alcanzado con el fallo emitido por el TDLC.

Además de las sanciones impuestas a las empresas coludidas, la principal repercusión de la sentencia del TDLC consistió en el reconocimiento de la necesidad de aumentar las multas frente a los acuerdos colusorios. Teniendo en cuenta que en la legislación vigente al momento de la sentencia se establecía un monto máximo imponible (30.00o UTA), se sugirió aumentar ese tope en proporción a los daños causados a los consumidores. ${ }^{89}$

La necesidad de incrementar la cuantía de las sanciones en dinero ante conductas de naturaleza colusiva ya se desprendía de lo comentado por el TDLC en el fallo examinado. En efecto, este organismo (a partir de diversos escenarios de sobreprecios cobrados por las empresas avícolas acusadas, durante toda la duración de la colusión) reconoció que en un "escenario muy conservador" se evidenciaban grandes diferencias entre los beneficios logrados por las coludidas en relación con las multas máximas que la ley permitía imponer. ${ }^{\circ \circ}$ No obstante esta observación, el Tribunal impuso a las empresas las multas atendiendo los límites máximos establecidos en la "Ley antimonopolios", teniendo en cuenta los niveles totales de ingresos de las empresas avícolas demandadas durante el último año de comisión de la conducta colusiva (esto es, el año 2010), a fin de respetar el principio de proporcionalidad de las sanciones y considerando la capacidad de pago de las multas por parte de las acusadas. ${ }^{91}$

89 Una opinión en este sentido, fue formulada por el ministro de economía, Luis Felipe Céspedes.

90 Tribunal de Defensa de la Libre Competencia, Contra Agrícola Agrosuper S. A y otros (2014, $\mathrm{n}^{\circ}$ I39/2014), Considerando Tricentésimo Quincuagésimo Quinto.

91 Para calcular el valor de las multas, el TDLC consideró como límite prudencial un 10\% del volumen total de negocios de la compañía en el último año de comisión de la conducta colusiva (2010). Véase TDLC Contra Agrícola Agrosuper S.A y otros (2014, n 139/2014), Considerando Tricentésimo Quincuagésimo Sexto. 
En sintonía con lo formulado por el TDLC dentro del caso, y como consecuencia del fallo analizado, representantes del Poder Ejecutivo reconocieron la necesidad de realizar cambios al sistema de la libre competencia proponiendo "el establecimiento de un sistema de multas sin topes basado en un porcentaje de las ventas de las empresas cartelizadas, e instaurando inhabilidades amplias a las personas naturales que operativizan el cartel".92 En conclusión, en conjunto con las repercusiones del denominado "Caso farmacias", el caso "Cartel de los pollos" coadyuvó en la generación del ambiente propicio para la presentación de las iniciativas legislativas a fin de sancionar más fuertemente la colusión en el ámbito económico, destacándose el proyecto de ley presentado por el Ejecutivo y contenido en el Boletín $\mathrm{N}^{\circ}$ 9.950-03 $3^{93}$, y que se convertiría en la Ley $\mathrm{N}^{\circ} 20.945$ del 2016. A continuación, se revisa el fortalecimiento del sistema de defensa de la libre competencia con énfasis en el tratamiento de las conductas colusivas, desde la perspectiva de la citada normativa.

\section{FORTALECIMIENTO DEL SISTEMA DE DEFENSA DE LA LIBRE COMPETENCIA Y MODIFICACIONES AL TRATAMIENTO DE LAS CONDUCTAS COLUSIVAS: LEY N ${ }^{\circ} 20.945$ DEL 2016}

Además de los efectos directos generados con el "Caso farmacias" y el caso "Cartel de los pollos" (como lo son el impulso a la promulgación de la Ley $\mathrm{n}^{0} 20.361$ del 2009 y la aplicación de la multa más alta permitida por la "Ley antimonopolios" por parte del TDLC, respectivamente), la discusión surgida a partir del desenlace de los dos acuerdos colusivos determinó la necesidad de fortalecer el sistema de defensa de la libre competencia, lo que exigió, entre otros cambios, la modificación del tratamiento de las conductas colusivas. Con base en las anteriores premisas, el Gobierno presentó una iniciativa con el propósito de ajustar su institucionalidad y así prevenir y sancionar adecuadamente las prácticas anticompetitivas, ${ }^{94}$

92 Así en portal de noticias FNE: «TDLC condenó a Agrosuper, Ariztía y Don Pollo por colusión» (disponible en: http://www.fne.gob.cl/2014/og/25/tdlc-condeno-a-agrosuper-ariztia-y-donpollo-por-colusion-y-ordeno-disolver-el-gremio-que-las-reune/, fecha de consulta: 20 octubre 2015).

93 Boletín disponible en: https://www.camara.cl/pley/pley_detalle.aspx?prmID=10362\&prmBoletin $=9950-03$, fecha de consulta 18 agosto 2017 .

94 Además del proyecto que se convertiría en la Ley n²0.945 del 2016, contenido en Boletín nº 
propuesta que se concretaría con la aprobación de la Ley $\mathrm{N}^{\circ} 20.945$ de 2016. A fin de concluir el estudio propuesto dentro del marco de la defensa de la libre competencia, se eximinará la citada ley con énfasis en aquellos cambios capaces de generar impacto en el combate de la colusión en materia económica.

\section{Fundamentos de la Ley $N^{\circ} 20.945$ del 2016}

Durante el inicio de la construcción legislativa que concluiría con la aprobación de la Ley $\mathrm{n}^{\circ} 20.945^{95}$ se reconocieron los avances logrados en Chile en materia de promoción y defensa de la libre competencia en los mercados, destacándose las modificaciones introducidas a partir de la Ley $\mathrm{n}^{0} 19.911$ de 2003 y de la Ley $\mathrm{n}^{0} 20.361$ de 2009. Sin embargo, a pesar de esta declaración, en la misma etapa preliminar también se planteó la necesidad de perfeccionar la institucionalidad en este ámbito de la economía, teniendo en cuenta dos presupuestos, esto es, el reconocimiento de la colusión como la "conducta que produce los efectos más graves en contra de la libre competencia y los consumidores" 96 , reconocimiento que va en sintonía con las reacciones generadas por los acuerdos colusivos atribuidos a las grandes empresas farmacéuticas y avícolas del país, y la necesidad de prevenir y sancionar adecuadamente las prácticas anticompetitivas, considerando la experiencia comparada y nacional en esta materia. ${ }^{77}$

9.950-03, se presentaron otras iniciativas en materia de defensa de la libre competencia con énfasis en la reincorporación de la sanción penal ante conductas colusorias. Por ejemplo, tenemos los proyectos contenidos en los Boletines 6438-03. 6439-07 y 6442-03.

95 Proyecto que ingresó el 19 de marzo del 2015.

96 Esta opinión es compartida por la Corte Suprema, autoridad que en su jurisprudencia afirma "que la colusión constituye de todas las conductas atentatorias contra la libre competencia la más reprochable, la más grave, ya que importa la coordinación del comportamiento competitivo de las empresas". Véase: Corte Suprema, Fiscalía Nacional Económica y la sociedad Explora Chile S.A. con Tribunal de Defensa de la Libre Competencia (recurso de reclamación); (2013, rol $\mathrm{n}^{\circ}$ 10954-2011).

97 Por ejemplo, un modelo exitoso a observar es el aplicado en los Estados Unidos, sistema que admite (como una de las herramientas más efectivas para la detección de carteles) la imposición de penas privativas de libertad a los ejecutivos y personas naturales que participen en acuerdos de carácter colusivo. Véase LizANA (2013) pp. 6-7. 


\section{Tratamiento de la colusión dentro de la Ley N ${ }^{\circ} 20.945$ del 2016}

Aunque la redacción de la Ley $\mathrm{N}^{\circ} 20.945$ tuvo como objetivo general afinar el sistema de la libre competencia, ${ }^{98}$ debe subrayarse que a partir del impacto de los casos que precedieron la presentación del proyecto el núcleo de esta normativa se concentró en el establecimiento de herramientas que permitieran combatir eficazmente la colusión en el plano económico. Además del tratamiento de las conductas colusivas, la propuesta original del Ejecutivo abarcó materias como el determinar un control preventivo y obligatorio de fusiones u operaciones de concentración, la confección de mejores herramientas para evaluar la competencia en los mercados y solucionar fallas de mercado o fallas regulatorias, la aplicación de las acciones y el procedimiento especial para la protección del interés colectivo o difuso de los consumidores (consagradas en la Ley $\mathrm{n}^{\circ}$ 19.496 de 1997), 99 la aplicación de sanciones para quienes entorpezcan las investigaciones de la FNE, y el ajuste del régimen a que están sometidos los ministros del TDLC.

Concentrado en las modificaciones efectivamente incorporadas en el marco exclusivo de la colusión y a partir de su grado de eficacia, se identifican tres cambios con un mayor nivel de incidencia en el combate de los acuerdos colusivos: ${ }^{100}$ la criminalización de la colusión, el fortalecimiento de la delación compensada y el aumento del monto máximo de las multas. La justificación de estas modificaciones, su contenido y las opiniones críticas que han surgido a partir de su implementación, se comentan a continuación.

98 Desde el punto de vista formal, la Ley $n^{\circ} 20.945$ modificó al DFL $n^{\circ}$ 1, de 2004, del Ministerio de Economía, que fijaba el texto refundido del Decreto Ley $\mathrm{n}^{\circ}{ }_{211}$, de 1973 , que fija normas para la defensa de la libre competencia.

99 Esta ley establece normas sobre protección de los derechos de los consumidores.

100 Aunque la criminalización de la colusión, el fortalecimiento de la delación compensada y el aumento del monto máximo de las multas son los instrumentos que generan un mayor impacto en la lucha contra la colusión, debemos mencionar otras figuras reconocidas dentro del marco del Decreto Ley $\mathrm{n}^{\circ} 211$ reformado, herramientas que coadyuvan en esta esfera de la defensa de la libre competencia. Estamos haciendo referencia al sometimiento de los agentes económicos que efectúen futuras operaciones de concentración (artículo 46 a 61, Decreto Ley ${ }^{\circ}$ 211, de 1973), y a la prohibición de contratar a cualquier título con órganos de la administración centralizada o descentralizada del Estado, así como la prohibición de adjudicarse cualquier concesión otorgada por el Estado [letra d), artículo 26, Decreto Ley nº 211, de 1973]. 


\section{A) Criminalización de la colusión}

Durante la redacción de la ley los legisladores reconocieron la "necesidad y legitimidad de volver a criminalizar conductas anticompetitivas", ${ }^{101}$ siendo el verdadero foco de discusión la fórmula que debía contemplarse para que este nuevo procedimiento fuera realmente efectivo (permitiendo a la institucionalidad avanzar) y no estancarse en cuanto a su resultados..$^{102}$ Esta "necesidad y legitimidad" de volver a sancionar penalmente las conductas anticompetitivas se sustentó en dos consecuencias directas generadas ante la ocurrencia de los acuerdos contrarios a la libre competencia, atribuidos a las grandes empresas farmacéuticas y avícolas del país: la magnitud de los efectos patrimoniales adversos para las víctimas, y la pérdida de confianza de los ciudadanos en la economía de mercado.

Dentro de la iniciativa se propuso incorporar al Código Penal un nuevo artículo 286 bis, encargado de tipificar el delito de colusión, con la pretensión de castigar únicamente a los denominados "carteles duros" (o hardcore cartels). ${ }^{103}$ Igualmente, junto con la tipificación de la colusión, se establecían las penas a imponer (principales y accesorias), y su dosificación. Sin embargo, esta fórmula entregaba a la FNE el ejercicio exclusivo y discrecional de la respectiva querella, y de presentar el requerimiento ante el TDLC, incluso de manera simultánea, pudiendo por tanto existir casos en que, por los mismos hechos, se hiciera a una persona enfrentar dos procedimientos al mismo tiempo ante distintos tribunales. ${ }^{104}$

A fin de evitar una posible duplicidad procedimental finalmente el legislador optó por incorporar el nuevo tipo penal dentro del artículo 62 de la Ley $\mathrm{N}^{\circ}$ 20.945, norma según la cual incurre en esta conducta "el que celebre u ordene celebrar, ejecute u organice un acuerdo que involucre a dos o más competidores entre sí, para fijar precios de venta o de compra de bienes o servicios en uno o más mercados; limitar su producción o provisión; dividir, asignar o repartir zonas o cuotas de mercado; o afectar el resultado de licitaciones realizadas por empresas públicas, privadas prestadoras de servicios públicos, u órganos públicos". El artículo 62, además, establece las penas

101 Boletín n 9.950-03 p. 8.

102 Avilés (2017) p.16.

103 Boletín n 9.950-03 p. 10.

104 Avilés (2017) p.16. 
a imponer ante la realización de los comportamientos colusivos ${ }^{105}$ y los mecanismos de dosificación (estipulando directrices en este ámbito). ${ }^{106}$

Una novedad procedimental que ha generado controversia (dado que un sector abogaba porque la acción pudiera estar en manos también del Ministerio Público) ${ }^{107}$ tiene que ver con la iniciativa de la acción penal, la cual solo puede ser planteada mediante querella por la $\mathrm{FNE}$, "sin que sea admisible denuncia o cualquier otra querella" exigiéndose además, como requisito previo, la dictación de sentencia definitiva ejecutoriada del TDLC, siendo facultad del Fiscal Nacional Económico determinar la interposición de la querella, teniendo carácter obligatorio en "aquellos casos en que se tratare de hechos que comprometieren gravemente la libre competencia en los mercados", lo que deberá emitirse por resolución fundada. ${ }^{108}$ Pese a la controversia surgida, piense que la iniciativa de la acción penal tal como está consagrada es coherente con el carácter específico y técnico de las materias que competen a los órganos especiales existentes para ello.

Como observación final en este punto referido a la sanción penal de las conductas colusorias y a raíz de la aprobación de la ley, en las primeras aproximaciones que se han efectuado a esta figura de la colusión (como forma de agresión a intereses dignos de protección por el Derecho Penal), la doctrina ha planteado la necesidad de identificar algunos factores a objeto de abordar de manera más sencilla el problema de la gravedad de la colusión y permitir legitimar su criminalización. Se sugiere que las decisiones de criminalización se restrinjan a conductas especialmente intolerables contra los intereses protegidos, ${ }^{109}$ lo cual implica que no cualquier acuerdo colusorio puede ser tenido como idóneo para dichos efectos

105 Respecto a las penas a imponer ante la realización de los comportamientos colusivos, los incisos $1^{\circ}$ y $2^{\circ}$ del artículo 62 establecen que "será castigado con la pena de presidio menor en su grado máximo a presidio mayor en su grado mínimo", lo que equivale a una pena de privación de libertad que va desde los 3 años y un día, hasta 10 años. Asimismo, "será castigado con inhabilitación absoluta temporal, en su grado máximo, para ejercer el cargo de director o gerente de una sociedad anónima abierta o sujeta a normas especiales, el cargo de director o gerente de empresas del Estado o en las que éste tenga participación, y el cargo de director o gerente de una asociación gremial o profesional".

106 Para efecto de la dosificación de la pena, el artículo 62 no acude a los artículos 67 a 69 del Código Penal, ni tampoco a las reglas especiales de determinación de las penas establecidas en otras leyes, estipulando sus propias directivas en la parte final de la norma.

107 Avilés (2017) p.16.

108 Artículo 64, incisos $1^{\circ}, 2^{\circ}$ y $3^{\circ}$, Ley n ${ }^{\circ} 20.945$, del 2016.

109 LuZón (2016) p. 88. 
sino que solo en cuanto presente la entidad suficiente para incidir en la fijación del precio de los bienes y servicios por encima del nivel competitivo (factor conocido como "poder de mercado"). ${ }^{110} 11$

\section{B) Fortalecimiento de la delación compensada}

Se puede definir la delación compensada como el mecanismo que busca inducir la deserción de al menos uno de los miembros del cartel, al cual se le ofrece una reducción o anulación total de la sanción a cambio de confesar su participación en el delito y entregar pruebas que permitan, en forma indiscutible, inculpar al resto de los miembros de la organización. ${ }^{112}$ Tomando como punto de partida este concepto y frente a la necesidad de fortalecer la detección y desestabilización de carteles, durante la construcción de la Ley $\mathrm{n}^{\circ} 20.945$ el reforzamiento de la delación compensada se basó en dos directrices, ${ }^{113}$ primeramente, estableciendo que el espectro de las sanciones respecto de las cuales puede otorgarse una exención o reducción debe ser más amplio que la multa y, en segundo lugar, confiriendo el beneficio de exención de responsabilidad criminal al primero que aporte antecedentes a la FNE, y de reducción de las multas y de la prohibición de contratar con el Estado a los demás partícipes del acto colusivo.

El artículo 63 de la Ley n 20.945 estableció la procedencia y requisitos de la delación compensada, ${ }^{14}$ en la cual se excluye de responsabilidad penal por el delito de colusión a las personas que primero hayan aportado antecedentes a la FNE, ${ }^{115}$ incorporando además una atenuante calificada

110 ARTAZA (2017) p. 360.

111 Se define como "poder de mercado" a la "habilidad de una empresa para elevar los precios por encima del nivel competitivo". Véase MotтA (2009) pp. 40-41.

112 GonzÁlez (2007) p. 6.

113 La Ley no 20.361 de 2009 ya había establecido una especia de "auto-denuncia" o "delación compensada" (mecanismo que no es denominado de esta forma en el texto de citada norma), figura que remitía a los involucrados en este tipo de conductas a acceder a una reducción o exención de la multa, siempre y cuando aportaran a la FNE antecedentes que condujesen a la acreditación de dicho comportamiento y a la determinación de los responsables.

114 La delación compensada penal del artículo 63 es similar a la establecida por el Artículo 39 Bis de la misma Ley $\mathrm{n}^{\circ}$ 20.945, norma que permite al infractor obtener la exención o rebaja de multas ante infracciones a la letra a) del artículo $3^{\circ}$ del modificado Decreto Ley $n^{\circ} 211$, de 1973.

115 El artículo 63, inciso $1^{\circ}$, estipula que "estarán exentos de responsabilidad penal por el delito tipificado en el artículo 62 aquellas personas que primero hayan aportado a la Fiscalía Nacional Económica antecedentes de conformidad al artículo 39 bis. El requerimiento del Fiscal Nacional Económico individualizará a las personas exentas de responsabilidad penal y dicha calidad será así 
a quien entregue antecedentes adicionales. ${ }^{116}$

La pregunta que surge es determinar el grado de eficacia de la delación compensada como herramienta para descubrir, sancionar e inhibir la existencia de acuerdos colusorios, y la experiencia nacional y comparada demuestra que, siempre que se ofrezcan los incentivos adecuados, la delación es un instrumento altamente efectivo en el combate de este tipo conductas contrarias a la libre competencia.

En el escenario anterior y en el ámbito de la experiencia nacional, los resultados alcanzados con la aplicación del mecanismo se evidencian en las sanciones impuestas a diversos agentes que habían incurrido en acuerdos colusorios, desde la promulgación de la Ley n⿳0 20.361 de 2009.

Por ejemplo, se tienen los siguientes casos:

i) "Compresores": Whirlpool S.A. fue condenada al pago de una multa de 10.500 U.T.A. a raíz de la confesión de la empresa Tecumseh Do Brasil Ltda. de haber formado parte (por lo menos desde el año 2004) de un cartel internacional junto con Whirlpool, Danfoss, ACC y Matsushita, cuyo objeto fue incrementar ilícita y artificialmente el precio de los compresores herméticos para refrigeración; ${ }^{117}$

ii) "Atevil": Servicios Pullman Bus Costa Central S.A. y otros agentes fueron multados y Atevil Mecánica Diesel S.A. recibió el beneficio de exención de multa por confesar un acuerdo de fijación de tarifas al público y de reparto de frecuencias para la prestación del servicio de transporte público de pasajeros; ${ }^{118} \mathrm{y}$

iii) "Asfaltos": en Asfaltos Chilenos S.A. y otros agentes fueron multados y condenados a implementar un programa de cumplimiento en materia de

declarada por el Tribunal de Defensa de la Libre Competencia".

116 El artículo 63, inciso $4^{\circ}$, establece que "se le rebajará en un grado la pena determinada, según lo que dispone el inciso tercero del artículo 62, a aquellas personas que hayan aportado a la Fiscalía Nacional Económica antecedentes adicionales de conformidad al inciso cuarto del artículo 39 bis. El requerimiento del Fiscal Nacional Económico individualizará a los beneficiarios de rebaja de la pena y dicha calidad será así declarada por el Tribunal de Defensa de la Libre Competencia".

117 Tribunal de Defensa de la Libre Competencia, Contra Whirlpool S.A. (2012, $\mathrm{n}^{\circ}$ 122/2012).

118 Tribunal de Defensa de la Libre Competencia, Contra Atevily otros (2014, n¹33/2014). 
libre competencia, y la Empresa Nacional de Energía Enex S.A. fue eximida del pago de multa por confesar la celebración de acuerdos para asignar contratos específicos de provisión de productos asfálticos utilizados en obras viales."19 Finalmente, un caso mediático es el conocido como "Cartel del Confort", en el cual a la empresa SCA le fue impuesta un multa de 20.00o U.T.A. a raíz de un acuerdo celebrado con CMPC Tissue S.A. y cuyo objeto fue la asignación de cuotas de participación de mercado y fijación de precios de venta de sus productos tissue desde el año 2000 hasta, a lo menos, diciembre del año 2011, afectando el mercado de la comercialización mayorista de papeles suaves en el canal de venta masivo; CMPC decidió auto-denunciarse y aportar antecedentes a la investigación a cambio de eximirse de multas, beneficio que efectivamente se otorgó. ${ }^{20}$

En la experiencia comparada la evidencia demuestra la efectividad de la delación compensada en la lucha contra los carteles. En Estados Unidos un análisis empírico confirmó que la aplicación de esta herramienta redujo la formación de carteles en un 42 \% e incrementó su detección en un $62 \% .{ }^{121}$ Igualmente, a partir de información recabada por el US Justice Department, se ha demostrado que el principal medio utilizado por la Antitrust Division para descubrir posibles acuerdos de cartel lo constituyen los programas de indulgencia individual y corporativa. ${ }^{122}$ Resultados análogos a los comentados se presentan en la Unión Europea, en donde se ha establecido que más de un $75 \%$ de los casos de colusión conocidos por la Comisión Europea, entre los años 2006 y 2013, tienen su origen en la delación compensada. ${ }^{123}$ Para concluir, cabe resaltar que en el espectro regional también se reconoce la importancia de los acuerdos de clemencia o delación compensada en la detección de los carteles y para la construcción de casos muy sólidos, dada la dificultad de identificar evidencias del ilícito en el que incurre el cartel. ${ }^{24}$

119 Tribunal de Defensa de la Libre Competencia, Contra Asfaltos Chilenos S.A. y otros (2015, $\mathrm{n}^{\circ}$ 148/2015).

120 Tribunal de Defensa de la Libre Competencia, Contra SCAy otro (2017, $\mathrm{n}^{\circ}$ 160/2017).

121 SокоL (2012) p. 206.

122 VARNeY y TeRZAKen (2013) p. 319.

123 Véase en Law360, 13 junio 2013, "Most Cartel Complaints Follow Leniency Apps, EU Says" (disponible en: https://www.law36o.com/articles/44989o fecha de consulta: 20 enero 2018).

124 Al respecto, tenemos los avances logrados en países como Brasil y Colombia. Véase en Revista EL EsPeCtAdDor (Colombia), 20 octubre 2017, "El nivel de sanciones que tiene Colombia es bajo". 


\section{C) Aumento del monto máximo de las multas}

La desproporción que se presentaba al contrastar el daño ocasionado a los consumidores y la cuantía de las multas definidas por las normas ${ }^{125}$ permitió reconocer el carácter insuficiente del monto máximo establecido originalmente en la ley (30.00o UTA) ${ }^{126}$ como herramienta para disuadir la comisión de ilícitos anticompetitivos (concretamente, los acuerdos colusorios) ${ }^{127}$ y con un doble objetivo preventivo-sancionatorio, durante la construcción de la Ley $\mathrm{n}^{\circ}$ 20.945, se propuso que el tope máximo de la multa ascendiera hasta una suma equivalente al doble del beneficio económico obtenido como resultado de la infracción, ${ }^{128} \mathrm{O}$ al 30\% de las ventas del contraventor correspondientes al período durante el cual la conducta sancionada se hubiese prolongado.

Estos criterios sugeridos para calcular el monto de la multa tienen su origen en la experiencia comparada sobre la materia. En Estados Unidos se establece como límite máximo para las multas el doble de la ganancia obtenida por el infractor o el doble de la pérdida causada a las víctimas y en el modelo europeo en se fija como límite máximo hasta un 30\% del valor de las ventas multiplicado por el número de años que haya durado la transgresión. ${ }^{129}$

Con la aprobación de la Ley $\mathrm{n}^{\circ}$ 20.945, los criterios antes sugeridos para fijar el tope máximo de las multas se mantuvieron pero fueron afinados y complementados. La ley estableció tres criterios:

i) Es posible aplicar multas hasta por una suma equivalente al 30\% de las ventas del infractor, "correspondientes a la línea de productos o servicios asociada a la infracción", durante el período por el cual ésta se haya extendido o hasta el doble del beneficio económico reportado;

125 Desproporción que se evidencia en casos como el "Cartel de los pollos" $y$ "Cartel del confort".

126 Monto que, hasta antes de la aprobación de la Ley $\mathrm{n}^{\circ}$ 20.945, era el establecido en el artículo 26, inciso segundo, letra c) del Decreto Ley no 211 , de 1973.

127 La Corte Suprema estima que la multa debe implicar "al menos un costo mayor al beneficio esperado" por infringir la ley. Véase Corte Suprema, Compañía Chilena de Fósforos con Tribunal de Defensa de la Libre Competencia (recurso de reclamación); (2010, rol n 277-2010), Considerando 22.

128 Si es que éste podía ser determinado por el Tribunal.

129 Véase Historia de la Ley $\mathrm{N}^{\circ} 20.945$. 
ii) Es posible aplicar multas hasta el doble del beneficio económico reportado por la infracción; $y$

iii) En caso que no se pudiera determinar dicho beneficio se pueden aplicar multas hasta por una suma equivalente a 60.000 UTA. ${ }^{130}$

Igualmente, la nueva normativa se encargó de enumerar (se dice enumerar, ya que la ley acude a la expresión "entre otras") los criterios para imponer las sanciones dinerarias en los siguientes términos: "para la determinación de las multas se considerarán, entre otras, las siguientes circunstancias: el beneficio económico obtenido con motivo de la infracción, en caso que lo hubiese; la gravedad de la conducta, el efecto disuasivo, la calidad de reincidente por haber sido condenado previamente por infracciones anticompetitivas durante los últimos diez años, la capacidad económica del infractor y la colaboración que éste haya prestado a la Fiscalía antes o durante la investigación". ${ }^{131}$ De los criterios estipulados para imponer las multas, podemos identificar como circunstancias nuevas el efecto disuasivo y la capacidad económica del infractor.

Finalmente, un elemento a tener en cuenta en el fortalecimiento de la lucha contra las conductas colusivas lo constituye la compatibilidad de aplicación de multas con las sanciones de carácter penal, ${ }^{132}$ factor que cobra relevancia de acuerdo a lo establecido en el artículo $64^{\circ}$ de la Ley ${ }^{\circ}$ 20.945, ya que para iniciar la acción penal se requiere como presupuesto la sentencia definitiva del TDLC.

130 Nuevo texto, letra c) artículo 26 del modificado Decreto Ley $n^{\circ}$ 211, de 1973.

131 Nuevo texto, letra c) artículo 26 del modificado Decreto Ley $\mathrm{n}^{\circ} 211$, de 1973.

132 Nuevo texto, inciso final artículo 26 del modificado Decreto Ley n ${ }^{\circ} 211$, de 1973. 


\section{CONCLUSIONES}

1. Tomando como punto de partida la aprobación del Título $V$ de la Ley $\mathrm{n}^{\circ}$ 13.305 de 1959, pasando por el Decreto Ley no 211 de 1973 (o "Ley antimonopolios"), las leyes $\mathrm{n}^{0} 19.911$ de 2003 y $\mathrm{n}^{0} 20.361$ de 2009, hasta llegar a la Ley $\mathrm{n}^{\circ} 20.945$ de 2016, se observa que el fortalecimiento del combate a las conductas colusivas ha sido una permanente preocupación del legislador dentro del marco de la defensa de la libre competencia. No obstante, y desde la perspectiva histórica, el tratamiento otorgado a la colusión a nivel nacional se ha visto influenciado por la realidad económica de cada época, la que trascurre entre la intervención del Estado (característica del periodo anterior al 11 de septiembre de 1973), la liberación del mercado (sobre todo entre la década del 70 y finales de la década de los 8o), la entrada en escena de un universo masivo de consumidores que llegaron a compartir un rol protagónico con el mundo empresarial (década de los 90), hasta llegar a la fase de los grandes acuerdos colusorios y su impacto generado en la sociedad (mediados de la primera década del siglo XXI). La lucha contra la colusión se inició con una primera normativa que establecía una amplia (aunque insuficiente) legislación antimonopolios, incluso con sanciones de carácter penal, pero con una institucionalidad incipiente (consignada en el Título $V$ de la Ley $\mathrm{n}^{0} 13.305$ de 1959). Esta lucha se robusteció a partir de la promulgación de una ley más amplia y precisa, con una institucionalidad más fuerte (o "Ley antimonopolios"), normativa que a su vez fue complementada por otras leyes, en las que se crearon organismos como el TDLC y se aumentaron las multas pero suprimiéndose las sanciones de carácter penal (leyes $n^{\circ} 19.911$ de 2003 y $n^{\circ} 20.361$ de 2009).

2. En el escenario anterior, pese a los avances logrados hasta ese momento en este ámbito particular de la protección a la libre competencia, la ocurrencia y el desenlace de los acuerdos colusivos llevados a cabo por las empresas farmacéuticas y avícolas no solo generaron un nivel de rechazo trasversal en la sociedad sino que determinaron la necesidad de ajustar la normativa encargada de combatir las prácticas anticompetitivas, particularmente en lo referente a la colusión en el plano económico, con la premisa de que este comportamiento es el que produce los efectos más graves en contra de la libre competencia y los consumidores, teniendo en cuenta el grado de desproporción que se observaba al contrastar el daño ocasionado y la cuantía de las multas impuestas a los agentes económi- 
cos involucrados, circunstancia que se agravaba ante la ausencia de una sanción penal que sirviera como mecanismo disuasorio para evitar estas conductas ilícitas. Bajo estas consideraciones es que se redactó la Ley $n^{\circ}$ 20.945 de 2016, la que, con base en su grado de eficacia y apoyándose en la experiencia comparada y nacional, se reconocen tres cambios con un mayor grado de incidencia en el combate de los acuerdos de naturaleza colusiva: la criminalización de la colusión, el fortalecimiento de la delación compensada y el aumento del monto máximo de las multas.

\section{BIBLIOGRAFÍA CITADA}

ARTAZA, Osvaldo (2017): "La colusión como forma de agresión a intereses dignos de protección por el Derecho Penal. Primera aproximación", Rev. derecho (Valdivia), volumen $30 \mathrm{n}^{0}$ 2, pp. 339-366. Disponible en: https://scielo.conicyt.cl/pdf/revider/v3on2/art15.pdf, fecha de consulta: 23 septiembre 2017.

Avilés, Jorge (2017): La Nueva Ley de Libre Competencia y los Desafíos de la Criminalización de la Colusión (Santiago, Libertad y Desarrollo).

Bernedo, Patricio (2013): Historia de la libre competencia en Chile, 1959-2010 (Santiago, FNE).

Carrasco, Camilo (2009): Banco Central de Chile 1925-1964, Una historia Institucional. Vol. XIV (Santiago, BCC).

Centro de Estudios Públicos (1992): "El Ladrillo": Bases de la Política Económica del Gobierno Militar Chileno ( $2^{\mathrm{a}}$ edición, Santiago, CEP). (1997): Los mil días de Allende (Santiago, CEP).

Fiscalía Nacional Económica (2010): Balance cuatrienio 2006-2010 (Santiago, FNE).

GonzÁlez, Aldo (2007): Conceptos y Aplicación de la Delación Compensada en la Persecución de los Carteles (Santiago, Expansiva). 
(2011): "Prácticas colusivas", en VV.AA. La libre competencia en el Chile del bicentenario (Santiago, Thomson Reuters) pp. 143-161.

HeRnÁnDeZ, Héctor (2012): "La punibilidad de la colusión (secreta) de precios en el Derecho chileno", Polít. crim, vol. 7, n ${ }^{13}$, pp. 147-167. Disponible en: http://politcrim.com/wpcontent/uploads/2019/o4/ Vol7N13A4.pdf, fecha de consulta: 20 octubre 2017.

HovenKAmP, Herbert (2003): "Política antitrust, federalismo y la teoría de la firma: una perspectiva histórica", Themis, n 43, pp. 7-18. Disponible en: http://revistas.pucp.edu.pe/index.php/themis/article/download/9837/10249, fecha de consulta: 14 septiembre 2017.

LizANA, Claudio (2013): "Delito de colusión en Chile ¿Una ley insuficiente?", Revista del Abogado, n 58, pp. 6-9.

Luzón, Diego (2016): Derecho Penal. Parte general ( $3{ }^{\text {a }}$ edición, Buenos Aires, Editorial B de $f$ ).

Motta, Massimo (2009): Competition Policy. Theory and Practice (Cambridge, Cambridge University Press).

OrtúZAR, Waldo (1978): "Ley Antimonopolios", Boletín de Investigaciones, $\mathrm{n}^{\mathrm{O}} 4 \mathrm{O}, \mathrm{pp} .127^{-132}$.

PARedes, Ricardo (1995): "Jurisprudencia de las Comisiones Antimonopolios en Chile", Revista de Estudios Públicos, nº 58, pp. 227-320.

Samuelson, Paul y Nordhaus, William (2006): Economía (Trad. María CevaIlos Almada, $18^{\mathrm{a}}$ ed., México D.F., Editorial Mc Graw-Hill).

SMITH, Adam (1794): Investigación sobre la naturaleza y las causas de la riqueza de las naciones (Trad. José Alonso Ortiz, Valladolid, Oficina de la Viuda e Hijos de Santander).

Sokol, Daniel (2012): "Cartels, Corporate Compliance, and What Practitioners Really Think About Enforcement", Antitrust Law Journal, vol. 78, $\mathrm{n}^{\circ} 1$, pp. 201-240. 
TIRONI, Eugenio (1999): La irrupción de las masas y el malestar de las elites: Chile en el cambio de siglo (Santiago, Grijalbo).

Varney, Christine y Terzaken, John (2013): "United States", The Cartels and Leniency Review, pp. 318-357. Disponible en: https://www.cravath.com/ files/uploads/documents/publications/3394022_1.pdf, fecha de consulta: 26 octubre 2017 .

\section{NORMAS JURÍDICAS CITADAS}

Código Penal, del 12 de noviembre de 1874.

Comisión Preventiva, Dictamen no 818 del 20 de agosto de 1992.

Comisión Resolutiva, Resolución nº 397 del 21 de septiembre de 1993.

Comisión Resolutiva, Resolución nº 6 del 23 de octubre de 1974.

Decreto Ley $n^{\circ}$ 211, de 22 de diciembre de 1973, Fija normas para la Defensa de la Libre Competencia.

Decreto Ley $\mathrm{n}^{\circ}$ 2.760, de 5 de julio de 1979, Modifica Decreto Ley ${ }^{\circ} 211$ de 1973, que Fija normas para la Defensa de la Libre Competencia.

Ley $\mathrm{n}^{\circ}$ 13.305, de 6 de abril de 1959, Reajusta las remuneraciones de todos los empleados que prestan servicios en Chile y modifica las leyes que señala.

Ley $\mathrm{n}^{0} 15.142$, de 22 de enero de 1963, Consulta normas para favorecer la distribución, comercialización y transporte de productos y reprimir los monopolios a excepción de los artículos que indica.

Ley $\mathrm{n}^{0}$ 19.496, de 7 de marzo de 1997, Establece normas sobre protección de los derechos de los consumidores.

Ley $\mathrm{n}^{0}$ 19.610, de 19 de mayo de 1999, Fortalece las atribuciones de la Fiscalía Nacional Económica. 
Ley $\mathrm{n}^{\circ}$ 19.911, de 14 de noviembre de 2003, Crea el Tribunal de Defensa de la Libre Competencia.

Ley $\mathrm{n}^{0}$ 20.361, de 13 de julio de 2009, Modifica el Decreto con Fuerza de Ley del Ministerio de Economía, Fomento y Reconstrucción de 2005, sobre Tribunal de Defensa de la Libre Competencia.

Ley $\mathrm{n}^{\circ}$ 20.945, de 30 de agosto del 2016, Perfecciona el Sistema de Defensa de la Libre Competencia.

Sherman Antitrust Act, United States of America, $1^{\circ}$ july 1890.

\section{JURISPRUDENCIA CITADA}

Corte Suprema, Compañía Chilena de Fósforos con Tribunal de Defensa de la Libre Competencia (recurso de reclamación); (2010): 2 de junio de 2010, rol n² 277-2010.

Corte Suprema, Fiscalía Nacional Económica y la sociedad Explora Chile S.A. con Tribunal de Defensa de la Libre Competencia (recurso de reclamación); (2013): 20 de septiembre de 2013, rol n 10954-2011.

Cuarto Tribunal Oral En lo Penal de Santiago, Contra Belloni yotros (2014): 28 de julio de 2015, rol n $^{\circ}$ 531-2014.

Tribunal de Defensa de la Libre Competencia, Contra Whirlpool S.A. (2012): 14 de junio de 2012, sentencia $n^{\circ} 122 / 2012$.

Tribunal de Defensa de la Libre Competencia, Contra Agrícola Agrosuper S.A yotros (2014): 25 de septiembre de 2014, sentencia $n^{\circ}$ I39/2014.

Tribunal de Defensa de la Libre Competencia, Contra Asfaltos Chilenos S.A. $y$ otros (2015): 23 de diciembre de 2015, sentencia n 148/2015.

Tribunal de Defensa de la Libre Competencia, Contra Atevily otros (2014): 15 de enero de 2014, sentencia $n^{\circ}$ 133/2014. 
Tribunal de Defensa de la Libre Competencia, Contra SCA y otro (2017): 28 de diciembre de 2017 , sentencia $\mathrm{n}^{\circ}$ 160/2017.

United States vs. Trans-Missouri Freight Ass'n, 166 U. S. 290 (1897)

United States vs. Addyston Pipe \& Steef Co. 85 F 271 6th Cir.1898, aff'd, 175 U.S. 211 (1899). 